\title{
SEROPREVALENCE AND RISK FACTORS OF ANTIBODIES AGAINST LEPTOSPIRA SPP. IN OVINES FROM UBERLÂNDIA MUNICIPALITY, MINAS GERAIS STATE, BRAZIL
}

\author{
Sandra R.S. Salaberry ${ }^{1 *}$; Vanessa Castro ${ }^{2}$; Alessandra F.C. Nassar ${ }^{2}$; Jacqueline R. Castro ${ }^{1}$; Ednaldo C. Guimarães ${ }^{3}$; Anna \\ M.C. Lima-Ribeiro ${ }^{1}$
}

${ }^{1}$ Faculdade de Medicina Veterinária, Universidade Federal de Uberlândia, Uberlândia, MG, Brasil; ${ }^{2}$ Instituto Biológico, São Paulo, SP, Brasil; ${ }^{3}$ Faculdade de Matemática, Universidade Federal de Uberlândia, Uberlândia, MG, Brasil.

Submitted: September 29, 2010; Approved: May 30, 2011.

\begin{abstract}
The objectives of the present study were to verify the seroprevalence of anti-Leptospira spp. antibodies, identify the most frequent serovars and the risk factors associated with the infection in Uberlândia, Minas Gerais, Brazil. A total of 334 ovines blood samples were collected in 12 farms from Uberlândia municipality to be evaluated by means the Microscopic Agglutination Test (MAT) against 22 serovars of Leptospira spp. and an epidemiologic questionnaire was applied for each farm in order to correlate with risk factors of leptospirosis: sex, age and breed as well as contact with cattle, contact with dogs and presence of rodents. The prevalence of seropositive to MAT was found in seventy four ovines (22.2\%; CI 95\% 17.6-26.4\%), with titers ranging from 100 to 3200. The most frequent serovars identified were: Hardjo, Autumnalis, Hardjo and Wolffi association and Grippotyphosa. Statistically significant differences were found in males, pure breeds and presence of rodents $(\mathrm{p}<0.05)$. The prevalence of anti-Leptospira spp. antibodies found in the present study demonstrated that this bacterium occurs in ovines of Uberlândia municipality, MG, Brazil. The need for the adoption of efficient management for the control of rodents and infection in ovines in order to avoid leptospirosis in the local flocks and future transmission to humans.
\end{abstract}

Key words: leptospirosis, seroprevalence, serovars, sheep

\section{INTRODUCTION}

Leptospirosis is a bacterial disease of the genus Leptospira that occurs in animals and humans (28). Through advances in genetics and molecular biology the Leptospira bacteria has been classified and divided into at least 12 pathogenic and four saprophytes species. The pathogenic species have been distributed into more than 250 serovars (1).
Humans can become infected by direct contact or indirectly by the urine of infected animals. The incidence of the disease is seasonal, varying by climatic conditions and humidity. The wet season, with elevated temperatures, is ideal for survival of the Leptospira in the environment (21).

Ovines seem to be less susceptible to leptospirosis infection than other domestic species. The most commonly diagnosed serovars include: Hardjo, Bratislava, Pomona and

*Corresponding Author. Mailing address: Laboratório de Doenças Infecto-Contagiosas da Faculdade de Medicina Veterinária da Universidade Federal de Uberlândia; Av. Ceará, s/nº- Bloco 2D- Sala 33- Campus Umuarama, Zip Code: 38400-902, Uberlândia, MG, Brasil.; Tel: +55 34 32182231.; E-mail: sandrasalaberry@yahoo.com.br 
Icterohaemorrhagiae. Once infected, animals may present clinical signs of fever, depression, anemia, hemoglobin deficiency and ictericia as well as abortion, stillbirths and sudden death (22). Ovines may become infected and transmit leptospirosis to other animals of their species (16).

Studies in the northeast of Italy, Greece and New Zealand have demonstrated the risks of transmission of leptospirosis to humans and the occurrence of anti-Leptospira spp. antibodies in ovines, with levels prevalence ranging between $5.7 \%$ and $6.1 \%(12,14,15)$. Seroepidemiological research on leptospirosis in ovines has been conducted and antibodies against Leptospira spp. were found in different regions of Brazil: States of São Paulo, Rio Grande do Norte, Rio Grande do Sul, Paraíba, Paraná and Rondônia $(8,6,18,19,17,2)$.

The objectives of the present study were to verify the prevalence of anti-Leptospira spp. antibodies, the predominant serovars and the risk factors associated with infection in ovines of Uberlândia municipality, Minas Gerais State, Brazil.

\section{MATERIALS AND METHODS}

The municipality of Uberlândia is situated in the macro region of the Triângulo Mineiro and Alto Paranaíba in the State of Minas Gerais, Brazil. The region has a tropical climate with two defined seasons, a wet summer and a dry winter. Average temperature and annual rainfall are approximately $22{ }^{\circ} \mathrm{C}$ and $1.500 \mathrm{~mm}$ respectively (11).

The present study was conducted on 12 properties that raise ovines in the municipality. The sample size was elaborated considering the total herd size of Uberlândia municipality, that compose 4,633 ovines (20), using a simple random sample (27). The adopted prevalence of $31.1 \%$ (25) were used with confidence interval of $95 \%$, and estimated error of 0.05 , establishing a sample size of 334 ovines. For determination of the number of animals to be examined per property a stratified proportional sample was selected using the formula: $n=n(N p) /(N)$, in which $n=$ sub sample size, $N p=$ herd size on the property and $\mathrm{N}=$ size of the county herd (5).

Blood samples were collected from the jugular vein of the clinically healthy ovines, of both sexes and varied ages and breeds. Disposable needles and vacuum tubes were used to receive the blood. The norms for treatment of research animals elaborated by the Ethics Committee of the Federal University of Uberlândia were followed (protocol number 054/09). Blood samples were sent to the Laboratory of Infectious Diseases of the Faculty of Veterinary Medicine located in the Federal University of Uberlândia for analysis. Following extraction of the coagulated portion, samples were transferred to microtubes and frozen at $-22{ }^{\circ} \mathrm{C}$ until processing.

Serum samples were tested by Microscopic Agglutination Test (MAT) at the Bacterial Reproduction Diseases Laboratory of the Biological Institute in São Paulo. MAT were performed using a collection of 22 live serovars of leptospira as antigens: Icterohaemorrhagiae, Canicola, Pomona, Grippotyphosa, Wolffi, Hardjo, Australis, Autumnalis, Bataviae, Bratislava, Butembo, Castellonis, Copenhageni, Cynopteri, Hebdomadis, Javanica, Panama, Pyrogenes, Shermani, Tarassovi, Whitcombi and Sentot. Initial sorting was done using a 1/100 dilution and the antigens that presented agglutination were titrated with the serovar reagents using a series of geometric dilutions with a ration of two, varying from $1 / 100$ to $1 / 3200$. The titer of the serovar was the reciprocal of the weakest dilution that presented a seropositive result. Calculation of the predominant serovar of the ovines was determined according to Castro et al. (13), considering the probable infecting serovar to be that presented the highest titer and was most frequent. When two or more serovars presented identical titers, the animals were discarded for purposes of this analysis. They were, however, considered as reactives for MAT. An exception was the association between the serovars Hardjo and Wolffi that, in function of a possible crossed reaction, were maintained in the analysis. The serovars of each farm, that were considered predominate, were those with the highest titer and reagent frequency. 
An epidemiological inquiry was conducted on each ovines farm to identify risk factors. Data were collected on sex, age and breed as well as contact with cattle, contact with dogs and presence of rodents, as recommended by Thrusfield (27). Statistical analysis was performed using the program Bioestat 5.0 (5), using a nonparametric test Odds Ratio for two independent samples to pool the results obtained, and risk factors at a significance level of $5 \%$.

\section{RESULTS}

From the whole blood samples analyzed, seventy four ovines (22.2\%; CI 95\% 17.6-26.4\%) were seropositive to one or more serovars, with titers ranging from 100 to 3200 (Table 1). Ovines were seropositive to ten serovars and the most frequent were Hardjo (23.6\%), Autumnalis (22.4\%), Grippotyphosa (14.4\%) and the association between Hardjo and Wolffi (17.9\%).

The number of ovines per farm ranged from $15.8 \%$ to $66.7 \%$ and the most prevalent serovars for each farm were Autumnalis $(83.3 \%$ to $100 \%)$, Australis (80\%), Hardjo (66.7\%) and Grippotyphosa (53.3\%) as presented in Table 2.

Based on the data collected on each farm, two (E and F) did not show animals with anti-Leptospira spp. antibodies. At these two farms the owners reported that the ovines had been vaccinated against leptospirosis. The remaining 10 farms did not vaccinate the ovines against leptospirosis.

Table 1. Distribution of ovines seropositive to Leptospira spp. according to serovar and their respective titers, by the Microscopic Agglutination Test, in Uberlândia Municipality, MG, Brazil, 2009.

\begin{tabular}{|c|c|c|c|c|c|c|c|c|}
\hline \multirow{2}{*}{ Serovar } & \multicolumn{6}{|c|}{ Titers } & \multirow{2}{*}{ Total } & \multirow{2}{*}{$\%$} \\
\hline & 100 & 200 & 400 & 800 & 1600 & 3200 & & \\
\hline Australis & 07 & - & - & - & - & - & 7 & 10.4 \\
\hline Autumnalis & 11 & 04 & - & - & - & - & 15 & 22.4 \\
\hline Canicola & 01 & - & - & - & - & - & 01 & 1.5 \\
\hline Castellonis & 03 & - & - & - & - & - & 03 & 4.5 \\
\hline Grippotyphosa & 04 & 04 & 01 & - & - & 01 & 10 & 14.9 \\
\hline Hardjo & 08 & 04 & 03 & 01 & - & - & 16 & 23.6 \\
\hline Hardjo-Wolffi ${ }^{*}$ & 04 & 04 & 04 & - & - & - & 12 & 17.9 \\
\hline Icterohaemorrhagiae & 01 & - & - & - & - & - & 01 & 1.5 \\
\hline Pomona & - & 01 & - & - & - & - & 01 & 1.5 \\
\hline Sentot & - & 01 & - & - & - & - & 01 & 1.5 \\
\hline
\end{tabular}

*Association between Hardjo and Wolffi.

Table 2. Number of ovines seropositive to Leptospira spp. and predominant serovar by the Microscopic Agglutination Test, in 12 flocks of Uberlândia Municipality, MG, Brazil, 2009.

\begin{tabular}{|c|c|c|c|c|c|c|}
\hline \multirow{2}{*}{ Farms } & \multicolumn{4}{|c|}{ Ovines } & \multicolumn{2}{|c|}{ Serovars } \\
\hline & $\mathrm{N}$ & $\mathrm{n}$ & Seropositive & $\%$ & Predominance & Frequency $\%$ \\
\hline $\mathrm{A}$ & 345 & 24 & 6 & 25 & Australis & 50 \\
\hline B & 591 & 43 & 10 & 23.3 & Hardjo-Wolffi & 30 \\
\hline $\mathrm{C}$ & 153 & 14 & 4 & 28.6 & Hardjo-Wolffi & 50 \\
\hline $\mathrm{D}$ & 382 & 30 & 6 & 20 & Autumnalis & 83.3 \\
\hline $\mathrm{E}$ & 580 & 41 & - & - & - & - \\
\hline $\mathrm{F}$ & 165 & 12 & - & - & - & - \\
\hline G & 500 & 35 & 15 & $42, .9$ & Grippotyphosa & 53.3 \\
\hline $\mathrm{H}$ & 1000 & 70 & 14 & 20 & Hardjo & 50 \\
\hline I & 512 & 38 & 6 & 15.8 & Hardjo-Wolffi & 50 \\
\hline $\mathrm{J}$ & 200 & 15 & 6 & 40 & Hardjo & 66.7 \\
\hline $\mathrm{L}$ & 35 & 3 & 2 & 66.7 & Autumnalis & 100 \\
\hline M & 90 & 9 & 5 & 55.6 & Australis & 80 \\
\hline
\end{tabular}

\footnotetext{
${ }^{\mathrm{N}}$ Number of ovines per farm.
}

${ }^{\mathrm{n}}$ Number of ovines per farm in the study. 
Significant differences $(\mathrm{p}<0.05)$ were observed for sex, breed and presence of rodents (Table 3). No significant differences were found to age, contact with cattle or contact with dogs.
According to the epidemiological data acquired $75.0 \%$ $(9 / 12)$ of the farms raised ovines for meat. The others produced breeding animals. All of the farms raised cattle although only $16.7 \%(2 / 12)$ allowed mixing of the two species.

Table 3. Proportion of ovines seropositive to Leptospira spp. by sex, age and breed and risk factors, in flocks of Uberlândia Municipality, MG, Brazil, 2009.

\begin{tabular}{|c|c|c|c|c|c|}
\hline \multirow[b]{2}{*}{ Variables } & \multicolumn{2}{|c|}{ Ovines } & \multirow[b]{2}{*}{$O \mathbf{r}^{\mathrm{a}}$} & \multirow[b]{2}{*}{$\mathrm{CI}^{\mathrm{b}} 95 \%$} & \multirow[b]{2}{*}{$\mathbf{P}$} \\
\hline & Total & Seropositive & & & \\
\hline \multicolumn{6}{|l|}{ Sex } \\
\hline Male & 18 & 8 & 3.04 & $1.15-7.99$ & 0.04 \\
\hline Female & 316 & 66 & - & - & - \\
\hline \multicolumn{6}{|l|}{ Age } \\
\hline $6-<12$ months & 62 & 12 & $0.65^{\mathrm{c}}$ & $0.32-1.33$ & 0.31 \\
\hline $1-4$ years & 101 & 16 & - & - & - \\
\hline$\geq 4$ years & 171 & 46 & - & - & - \\
\hline \multicolumn{6}{|l|}{ Breed } \\
\hline Crossbred & 173 & 27 & 0.45 & $0.26-0.76$ & 0.004 \\
\hline Pure & 161 & 47 & - & - & - \\
\hline \multicolumn{6}{|l|}{ Contact with cattle } \\
\hline Yes & 39 & 12 & 1.67 & $0.80-3.48$ & 0.24 \\
\hline No & 295 & 62 & - & - & - \\
\hline \multicolumn{6}{|l|}{ Contact with dogs } \\
\hline Yes & 281 & 59 & 0.67 & $0.35-1.30$ & 0.32 \\
\hline No & 53 & 15 & - & - & - \\
\hline \multicolumn{6}{|c|}{ Presence of rodents } \\
\hline Yes & 255 & 68 & 4.42 & $1.84-10.6$ & 0.0006 \\
\hline No & 79 & 6 & - & - & - \\
\hline
\end{tabular}

\section{DISCUSSION}

The prevalence value of anti-Leptospira spp. antibodies found in the present study was different of results presented by Santos (25) who detected a prevalence of $31.3 \%(72 / 230)$ in goats of the geographical area. The difference may have occurred since the goats of the region are raised for milk. They thus are kept for long periods of time on the properties. In contrast, ovines are raised to produce meat. In this exploration, ovines are kept for a shorter period in pasture, with less possibility of infection.

The results obtained in our study were superior to prevalence for leptospirosis in ovines found in other areas of Brazil: Barbudo Filho et al. (8) identified 8.6\% (73/846) with anti-Leptospira spp. antibodies in the State of São Paulo and Azevedo et al. (6) diagnosed 3.5\% seropositive for leptospirosis in Rio Grande do Norte. The results showed to be lower than observed by Herrmann et al. (18) that identified $34.26 \%$ (466/1360) agglutinated antibodies in Rio Grande do Sul, Aguiar et al. (2) who detected 33.3\% (47/141) of antibodies in Monte Negro municipality, Rondônia and Hashimoto et al. (17) that found 38.57\% (27/70) of ovines reactive to antibodies anti-Leptospira spp. in Jaguapitã municipality, Paraná. Seroprevalence research conducted in 
other states of Brazil has demonstrated a diversity of results for leptospirosis in ovines. These variations in prevalence in other regions of Brazil, may be due to management conditions, climatic variation or in the rainfall. All of these factors are associated with the dissemination of leptospirosis. It must be noted that tropical and subtropical regions, with heavy rainfall, can be expected to have occurrences of leptospirosis (10), explaining the results found in the present study.

The most prevalent serovars in our study were different from those cited by Pugh (22) as being most common in ovines except for Hardjo. We also identified the serovars Bratislava, Pomona and Icterohaemorrhagiae. The predominance of the serovar Hardjo has also been found by other papers. Herrmann et al. (18) described the serovar Hardjo as being the most prevalent and most frequent in regions of large properties and with concentrated production of cattle and ovines. Ribeiro et al. (24) also found a prevalence of $47.8 \%$ to serovar Hardjo in cattle from Uberlândia municipality. The serovar Hardjo are maintained by cattle that are adapted host for this serovar and are responsible for transmission to other species, principally small ruminants, which share the same pasture. However, studies have suggested that ovines established reservoir status or gradual host adaptation to serovar Hardjo (15), explaining the results on the present study: all studied farms analyzed raised cattle, but only two of them had cattle and ovines sharing pasture.

The serovars Hardjo and Wolffi may occur in association since they share antigens that may produce crossed reactions. Wolffi was not pointed as the most probable, even in association with Hardjo. These results are similar to found by Castro et al. (13), where $21.0 \%$ of reaction were associated with cross reaction between Hardjo and Wolffi.

Serovar Autumnalis detected as one of the most prevalent had already been previously found by Santos (25) in Uberlândia, with a frequency of $30.3 \%$ among goats, suggesting that this serovar could be transmitted among ovines and goats. Azevedo et al. (6) in Rio Grande do Norte State, detected $28.6 \%$ of ovines seropositive for serovar Autumnalis. Higino et al. (19) in Patos municipality, Paraíba State, found Autumnalis as the most frequent in ovines slaughtered in the public slaughterhouse, with five reactant sera from a total of six animals seropositive by MAT. This serovar have been detected in another regions from Brazil, not only in ovines, but also in dogs, equines and swines. Batista et al. (9) identified the majority of the dogs seropositive to Autumnalis, with a prevalence of $20.0 \%$. Other papers related this serovar among the most prevalent in equines and swines $(3,7)$. Serovar Autumnalis could be associated with presence of mouse and rats as primary reservoir hosts and could infect other species, like dog, human and domestic ruminants as incidental hosts (26). A research of sera from 276 humans living in 71 farms located in Monte Negro municipality, Rondônia, detected serovar Autumnalis $(10.0 \%)$ as the second most frequently found (4), demonstrating the possibility of infection in humans with this serovar.

Until the present time there is no commercial vaccine for the serovar Autumnalis for cattle, ovines or goats. For this reason it is, in general, important to identify the prevalent serovars of each region. With this information, effective vaccines can be sought that will produce more lasting immunological responses.

Serovar Grippotyphosa could be associated with presence of vole, raccoon and opossum as primary reservoir hosts and could infect dog, human, cattle, ovines and goats as incidental hosts $(23,26)$. In the present research, the presence of this serovar may be related to the presence of reservoir hosts on the properties.

The number of ovines seropositive per farm of the present study was found by Santos (25) among goats in the same municipality, who identified a frequency of between $12.5 \%$ and $70.0 \%$ seropositive animals on the properties examined. This frequency may occur due to the management and sanitation techniques used on the different properties. The variation among the serovars detected on the properties of the present 
study may also have been associated with sanitation factors as well as with animals that had been procured from other properties.

An increase in anti-Leptospira spp. antibodies in reproducing males could be considered a risk factor since leptospirosis can be transmitted in the semen (23), thus favoring the possibility of infection in healthy females. The predominance of pure breed could be occurred due the production of ovines was being a recent activity in the region with ram and pure breed animals acquired from other regions of Brazil, probably without knowledge of health status of ovines.

The presence of rodents also favors the occurrence of leptospirosis on the farm since rodents are considered a principal source of infection of Leptospira spp. (28). Leptospirosis in humans is always acquired from an animal source and this disease is regarded globally as a zoonosis (1). Studies have suggested that ovines may have become a significant source of human infection (16). However, more research is necessary to know about the reservoir or incidental host status of sheep as a significant source of infection to other livestock and humans and about the possible role of rodents to infect ovines. The presence of rodents in our study affirms the need for the adoption of measures to control rodents, which can excrete leptospiras in the urine, transmitting the infection to animals as well as humans.

Although $22.2 \%$ of the ovines of the present study were found to be seropositive for leptospirosis, none of them presented clinical signs of infection, an important factor since they could be asymptomatic carriers, disseminating the bacteria and guaranteeing their persistence in the environment (6). The possibility of infection thus persists for humans who are in contact with the animals and for contamination of the soil and water, for future infection (1).

The prevalence of anti-Leptospira spp. antibodies found in the present study demonstrated that this bacterium occurs in ovines of Uberlândia municipality, MG, Brazil. The need for the adoption of efficient management for the control of rodents and infection in ovines in order to avoid leptospirosis in the local flocks and future transmission to humans.

\section{REFERENCES}

1. Adler, B.; De La Peña Moctezuma, A. (2010). Leptospira and leptospirosis. Vet. Microb., 40, 287-296.

2. Aguiar, D.M.; Cavalcante, G.T.; Vasconcellos, S.A.; Souza, G.O.; Labruna, M.B.; Camargo, L.M.A.; Gennari, S.M. (2010). Anticorpos anti-Leptospira spp. em ovinos do município de Monte Negro, estado de Rondônia. Arq. Inst. Biol., 77, 529-532.

3. Aguiar, D.M.; Cavalcante, G.T.; Lara, M.C.C.S.H.; Villalobos, E.M.C.; Cunha, E.M.S.; Okuda, L.H.; Stéfano, E.; Nassar, A.F.C.; Souza, G.O.; Vasconcellos, S.A.; Labruna, M.B.; Camargo, L.M.A.; Gennari, S.M. (2008). Prevalência de anticorpos contra agentes virais e bacterianos em equídeos do Município de Monte Negro, Rondônia, Amazônia Ocidental Brasileira. Braz. J. Vet. Res. Anim. Sci., 45, 269-276.

4. Aguiar, D.M.; Cavalcante, G.T.; Camargo, L.M.A.; Labruna, M.B.; Vasconcellos, S.A.; Souza, G.O.; Gennari, S.M. (2007). Anti-Leptospira spp. and anti-Brucella spp. antibodies in humans from rural area of Monte Negro Municipality, State of Rondônia, Brazilian Western Amazon. Braz. J. Microbiol., 38, 93-96.

5. Ayres, M.; Ayres, Jr.M.; Ayres, D.L.; Santos, A.A.S. (2007). Bioestat 5.0. Aplicações estatísticas nas áreas das ciências bio-médicas. Sociedade Mamiaurá, Belém.

6. Azevedo, S.S.; Alves, C.J.; Andrade, J.S.L.; Batista, C.S.A.; Clementino, I.J.; Santos, F.A. (2004). Ocorrência de aglutininas anti-Leptospira em ovinos do estado do Rio Grande do Norte, Brasil. Rev. Bras. Cienc. Vet., $11,167-170$.

7. Azevedo, S.S.; Soto, R.M; Morais, Z.M.; Pinheiro, S.R.; Vuaden, E.R.; Batista, C.S.A.; Souza, G.O.; Delbem, A.C.B.; Gonçales, A.P.; Vasconcellos S.A. (2006). Frequency of anti-leptospires agglutinins in sows from a swine herd in the Ibiúna Municipality, State of São Paulo, Brazil. Arq. Inst. Biol., 73, 97-100.

8. Barbudo Filho, J.; Girio, R.J.S.; Mathias, L.A.; Oliveira, A.V.; Marinho, M. (1999). Pesquisa de anticorpos contra Leptospira interrogans em soros de ovinos do estado de São Paulo. Avaliação do sorotipo jequitaia de Leptospira biflexa como antígeno de triagem sorológica. Ars Vet., 15, 26-23.

9. Batista, C.S.A; Azevedo, S.S.; Alves, C.J.; Vasconcellos, S.A.; Morais, M.; Clementino, I.J.; Lima, F.S.; Araujo Neto, J.O. (2004). Soroprevalência de leptospirose em cães errantes da cidade de Patos, Estado da Paraíba, Brasil. Braz. J. Vet. Res. Anim. Sci., 41, 131-136.

10. Brasil (1995). Ministério da Saúde. Fundação Nacional da Saúde. 
Programa Nacional de Leptospirose. Manual de Leptospirose. Fundação Nacional da Saúde: Brasília, 98p.

11. Brito, J.L.S.; Prudente, T.D. (2005). Mapeamento do uso da terra e cobertura vegetal do município de Uberlândia-MG, utilizando imagens CCD/CBERS 2. Caminhos Geogr., 13, 144-153.

12. Burriel, A.R.; Dalley, C.; Woodward, M.J. (2003). Prevalence of Leptospira species among farmed and domestic animals in Greece. Vet. Rec., 153, 146-148.

13. Castro, V.; Azevedo, S.S.; Gotti, T.B.; Batista, C.S.A.; Gentili, J.; Moraes, Z.M.; Souza, G.O.; Vasconcellos, S.A.; Genovez, M.E. (2008). Soroprevalência da leptospirose em fêmeas bovinas em idade reprodutiva no estado de São Paulo, Brasil. Arq. Inst. Biol., 75, 3-11.

14. Ciceroni, L.; Lombardo, D.; Pinto, A.; Ciarrocchi, S.; Simboni, J. (2000). Prevalence of antibodies to Leptospira serovars in ovines and goats in Alto Adige-South Tyrol. J. Vet. Med. Ser. B., 47, 217-223.

15. Dorjee, S.; Heuer, C.; Jackson, R.; West, D.M.; Collins-Emerson, J.M.; Midwinter, A.C.; Ridler, A.L. (2008). Prevalence of pathogenic Leptospira spp. in ovines in a ovines-only abattoir in New Zealand. New Zeal. Vet. J., 56, 164-170.

16. Fernandes, C.E. (2009). Papel do ovino na cadeia epidemiológica da leptospirose pela Leptospira spp. sorovar Hardjo: fatores de risco que envolvem a infecção e transmissão entre ovinos e bovinos. São Paulo, Brasil, 101p. (M.Sc. Dissertation. Instituto Biológico. São Paulo).

17. Hashimoto, V.Y.; Garcia, J.L.; Spohr, K.A.H.; Silva, F.G.; Alves, L.A., Freitas, J.C. (2010). Prevalência de anticorpos contra Leptospira spp. em bovinos, caninos, equinos, ovinos e suínos do município de Jaguapitã, estado do Paraná, Brasil. Arq. Inst. Biol., 77, 521-524.

18. Herrmann, G.P.; Lage, A.P.; Moreira, E.C.; Haddad, J.P.A.; Resende,
J.R.; Rodrigues, R.O.; Leite, R.C. (2004). Soroprevalência de aglutininas anti-Leptospira spp. em ovinos nas mesorregiões Sudeste e Sudoeste do estado Rio Grande do Sul, Brasil. Cienc. Rural., 34, 443-448.

19. Higino, S.S.S.; Azevedo, S.S.; Alves, C.J.; Figueiredo, S.M.; Silva, M.L.C.R.; Batista, C.S.A. (2010). Frequência de leptospirose em ovinos abatidos no município de Patos, Paraíba. Arq. Inst. Biol., 77, 525-527.

20. Instituto Brasileiro de Geografia e Estatística. Censo Agropecuário 2006. Available at: http://www.ibge.gov.br/cidadesat /topwindow.htm?1. Acessed 25 Mar. 2008.

21. Levett, P.N. (2004). Leptospirosis: a forgotten zoonosis? Clin. Appl. Immunol. Rev., 4, 435-448.

22. Pugh, D.G. (2004). Clínica de ovinos e caprinos. São Paulo: Roca, 203204.

23. Radostits, O.M.; Gay, C.C.; Hinchcliff, K.W.; Constable, P.D. (2006). Veterinary Medicine. Philadelphia: W. B. Saunders, 1094-1110.

24. Ribeiro, S.C.A.; Bisinoto, D.P.; Oliveira, P.R. (2000). Prevalência da leptospirose em fêmeas reprodutoras bovinas do município de Uberlândia, MG. Vet. Not., 6, 69-75.

25. Santos, J.P. (2007). Soroprevalência e aspectos epidemiológicos da leptospirose caprina no municipio de Uberlândia, Minas Gerais, Brasil, 72p. (M.Sc. Dissertation. Ciências Veterinárias. UFU).

26. Sessions, J.K.; Greene, C.E. (2004).Canine leptospirosis: epidemiology, pathogenesis, and diagnosis. Compend. Contin. Educ. Pract. Vet., 26, 606-623.

27. Thrusfield, M. (2004). Epidemiologia Veterinária. São Paulo: Roca, $556 \mathrm{p}$.

28. World Health Organization. (2003). Human leptospirosis: guidance for diagnosis, surveillance and control. Malta: WHO Library, 109p. 